\title{
LINEAMENT STUDIES OF ROCKS IN OMIFUNFUN AREA, SOUTHWESTERN NIGERIA: REMOTE SENSING AND PETROLOGIC OBSERVATIONS
}

\section{ADELEYE YEKINI BIODUN ANIFOWOSE AND ADEMUYIWA ADETUNJI}

(Received 2 July 2014; Revision Accepted 21 August 2014)

\begin{abstract}
Omifunfun area is situated in the southern part of Ife-llesa Schist Belt of the basement complex of southwestern Nigeria. The study area is traversed by the Ifewara Fault Zone which divides the area into east-west with contrasting lithologies that have been variously mylonitized. To the east, is quartzite and to the west migmatite gneiss which are intruded by prophyritic granites. The objective of this study is to delineate deformation linear structures from Landsat imageries over the study area, and attempt to correlate the information with microtectonic structures and field observations with the aim of better understanding the geologic terrain. Lineaments were extracted from Landsat images covering Omifunfun area. The analysis of these lineaments indicates low density in three prominent orientations corresponding to $000^{\circ}-035^{\circ}$ and $060^{\circ}-090^{\circ}$ with minor northwest-southeast structures. The most prominent of these directions is the $000^{\circ}-035^{\circ}$ which incidentally include mylonite and mineral lineations within the Ifewara Fault system. Microtectonic observations reveal analogous results with three prominent foliation directions. The dominant one strikes in the same direction with the same Ifewara mylonitic foliation. These directions correspond to two major planar surfaces $S_{1}$ and $S_{2}$ and were respectively produced during two episodes of deformation $\left(D_{1}\right.$ and $\mathrm{D}_{2}$ ).
\end{abstract}

KEYWORDS: Ifewara Fault Zone, Lineament, Microtectonic Structures, Mylonitization, Remote Sensing

\section{INTRODUCTION}

Linear structures are characteristic of the Basement Complex of Nigeria. The oldest of these linear structures are the healed E-W fractures that have been filled with quartzo-feldspathic veins and dykes (Oluyide, 1988). The most prominent linear structures in Nigeria are the N-S fractures attributed to brittle deformation. Linear structures that can be interpreted from satellite imageries are dykes, rivers, rock contacts, fractures, ridges and man-made features. Penetrative deformation structures (foliations) are often distinct in the field and under polarizing microscopes. The combination of petrographic and field observations give an insight into the number of episodes of deformation an area has undergone. Remnants of early fractures are preserved in the migmatite gneiss terrain of southwestern Nigeria. Ground truthing serves as a means of confirming what constitutes the linear structure one is interpreting from satellite imageries.

The study area, which is a part of Ife-llesa Schist Belt is thought to be traversed by a major NNESSW fault zone that extends southwards to Omifunfun area and northwards to Ifewara (with a major bifurcation that passes through Iwaraja), east of Lafiagi and Zungeru in northern Nigeria. This represents the most prominent lineament system in Nigeria (Udoh, 1988). The Ifewara Fault Zone may have been affected by a combination of transcurrent and dip slip movements
(Odeyemi, 1998). Caby and Boesse (2002) attributed major structures in the area to the Pan-African synmetamorphic stacking of thrusted units above the Archaean basement and proposed the area to be part of a Pan-African nappe system observed at mid-crustal levels.

Analyses of SPOT, aerial photographic, topographic and aeromagnetic data and lineament studies indicate strong orientation of the lineaments in Ilesa Schist Belt to be NE-SW and ENE-WSW (Odeyemi, 1998). This type of analysis is useful for extracting lithologic and structural information over an inaccessible and poly-deformed basement terrain (Odeyemi, 1993). This study intends to highlight the major structural trend and what constitutes the linear structures in Omifunfun part of the Ife-llesa Schist Belt and support this with field and microtectonic evidences.

\section{Geological Setting}

Omifunfun is part of the Precambrian basement rock of southwestern Nigeria. The rocks in the area predominantly belong to the migmatite-gneiss complex, schistose quartzites and Pan-African porphyritic granites (Odeyemi, 1993) (Figure 1). The quartzite mostly occurs as ridges. These lithologies were affected by both plastic and brittle shear deformations which resulted into their folding and mylonitization. The Ifewara Fault Zone passes through this area, and as observed elsewhere in the Ife-llesa Schist Belt the lithologies on the either sides

Adeleye Yekini Biodun Anifowose, Department of Remote Sensing and GIS, Federal University of Technology, Akure, Nigeria.

Ademuyiwa Adetunji, Department of Applied Geology, Federal University of Technology, Akure, Nigeria. 
of the fault zone show a marked contrast (Odeyemi, 1993; Hubbard, 1975). The shear zone pattern in this part of the Nigerian basement indicates that the study area is the southern extension of central/eastern Hoggar
(Black et al., 1994). The basement has undergone a polycyclic tectono-thermal deformation and metamorphism (Ajibade and Wright, 1989) with the last one occurring during the Pan African (Rahaman, 1988).

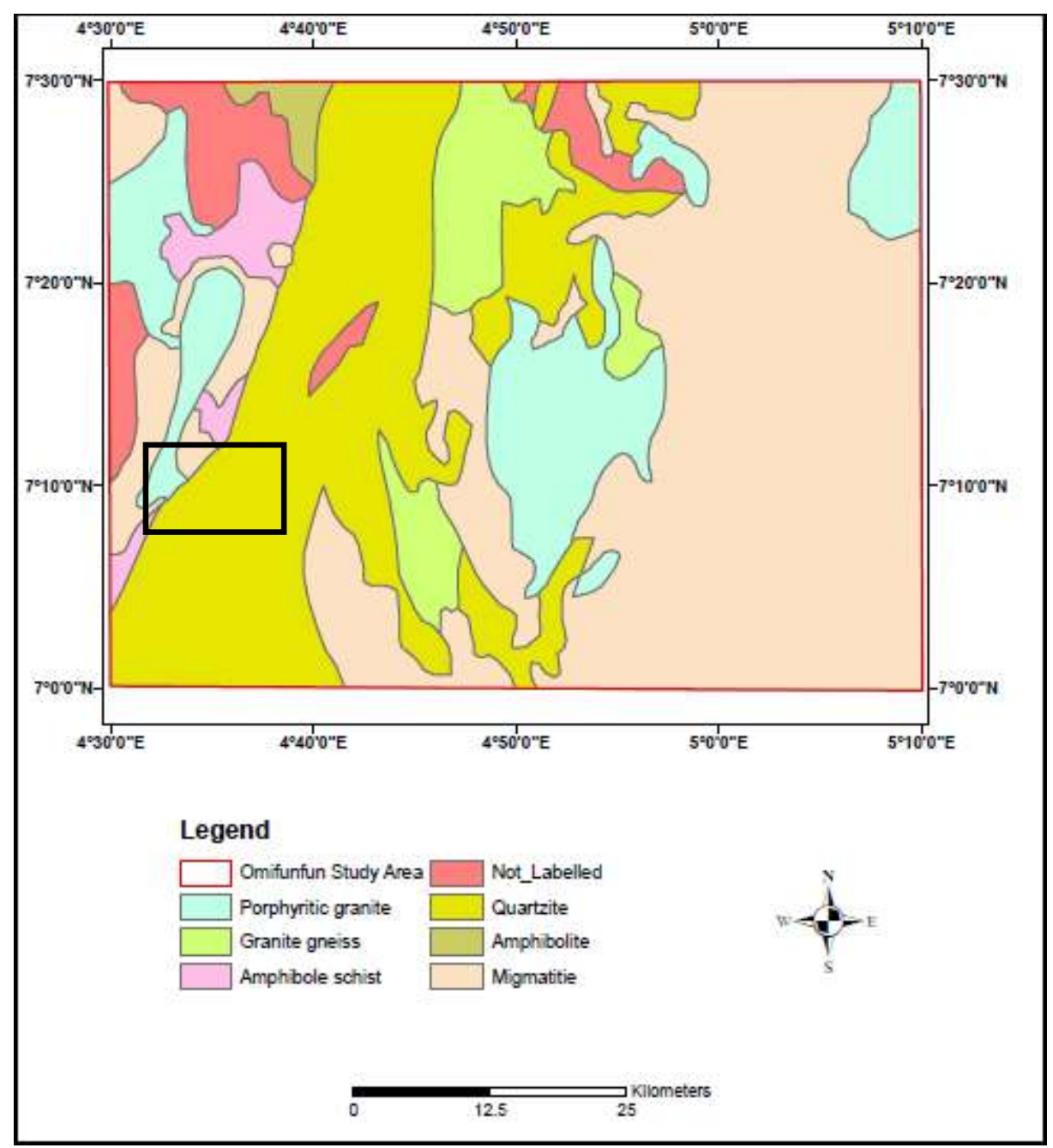

Fig. 1: Geological map of part of Ifewara Fault Zone [adapted from Odeyemi, 1993]. Study area in rectangular box

\section{MATERIAL AND METHODS}

Landsat imageries covering the study area were downloaded from http://www.landsat.org. A handheld Global Positioning System (GPS), a compass clinometer, 1:50,000 topographical map of Ondo SW (Sheet $263 \mathrm{SW}$ ) and a monocular polarizing microscope were used in the study. The imageries in six colour bands were processed into false colour composites to three bands using ILWIS ${ }^{\mathrm{TM}} 3.5$ version. Lineaments were visually extracted from the imagery and topographical map, and then digitized to form the basis of lineament map for the area (Figure 2). During ground truthing, representative rock samples were collected for petrographic studies. Microstructures and relationships among the various mineral compositions were delineated. 


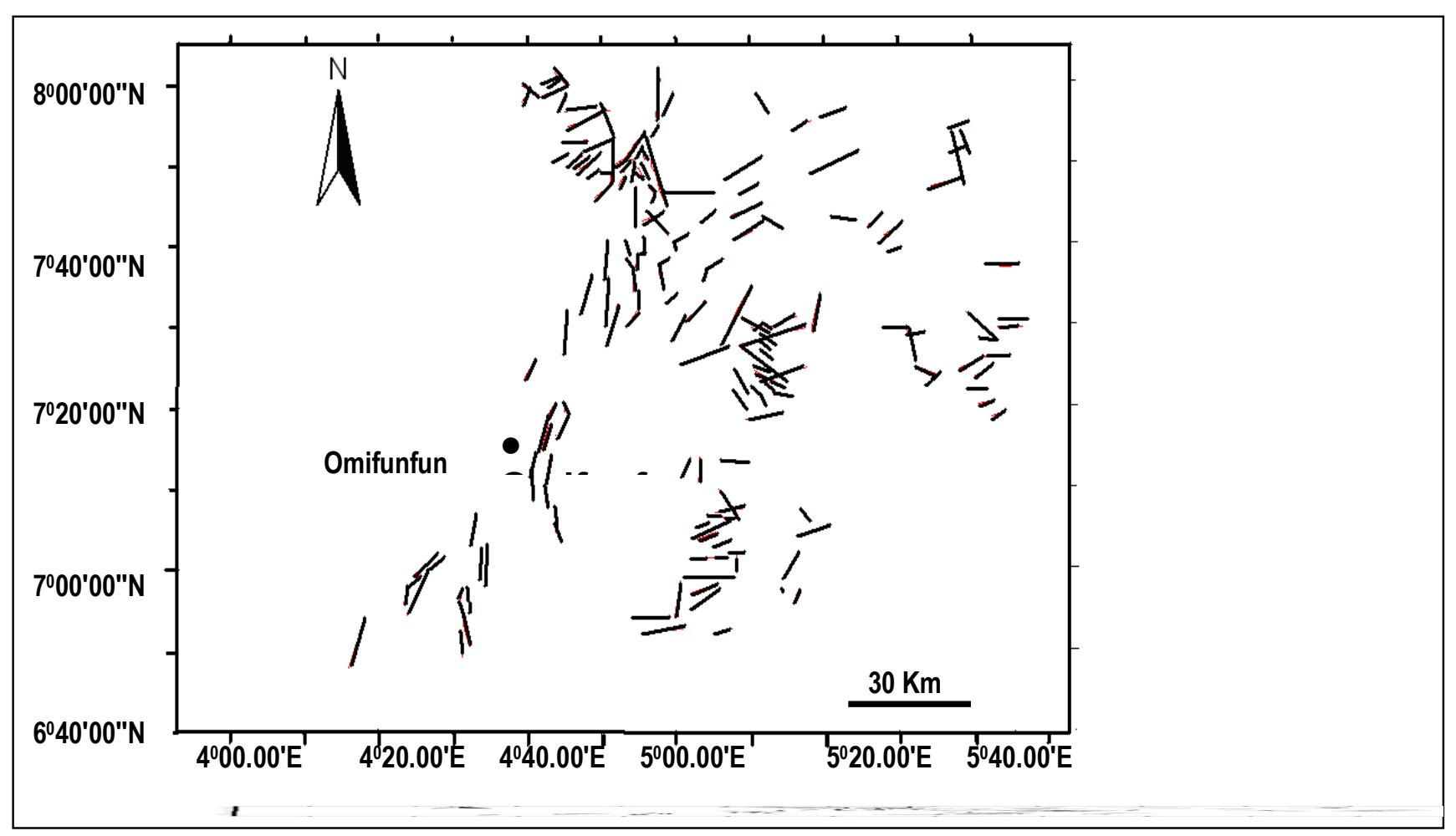

Fig. 2: Lineament map of the region around the study area.

\section{RESULTS AND DISCUSSION}

The possible lineaments are lithologic boundaries, fractures (joints and faults), drainage, road network, dykes and settlements. The lineaments were interpreted from azimuth frequency/length and frequency/length diagrams (Figures 3 and 4). These diagrams show a polymodal distribution of the lineaments. Two peaks were observed to correspond to ENE-WSW $\left(060^{\circ}\right)$ and NNE-SSW $\left(035^{\circ}\right)$ with minor NW-SE structures. Equally, from Figure 4, the fractures show polymodal peak distribution along NW-SE $\left(135^{\circ}\right)$, ESE-WNW $\left(095^{\circ}\right)$ and ENE-WSW $\left(070^{\circ}\right)$. The lineament map shows that the area has low density fractures with the dominant ones being along NNE-SSW (035). 


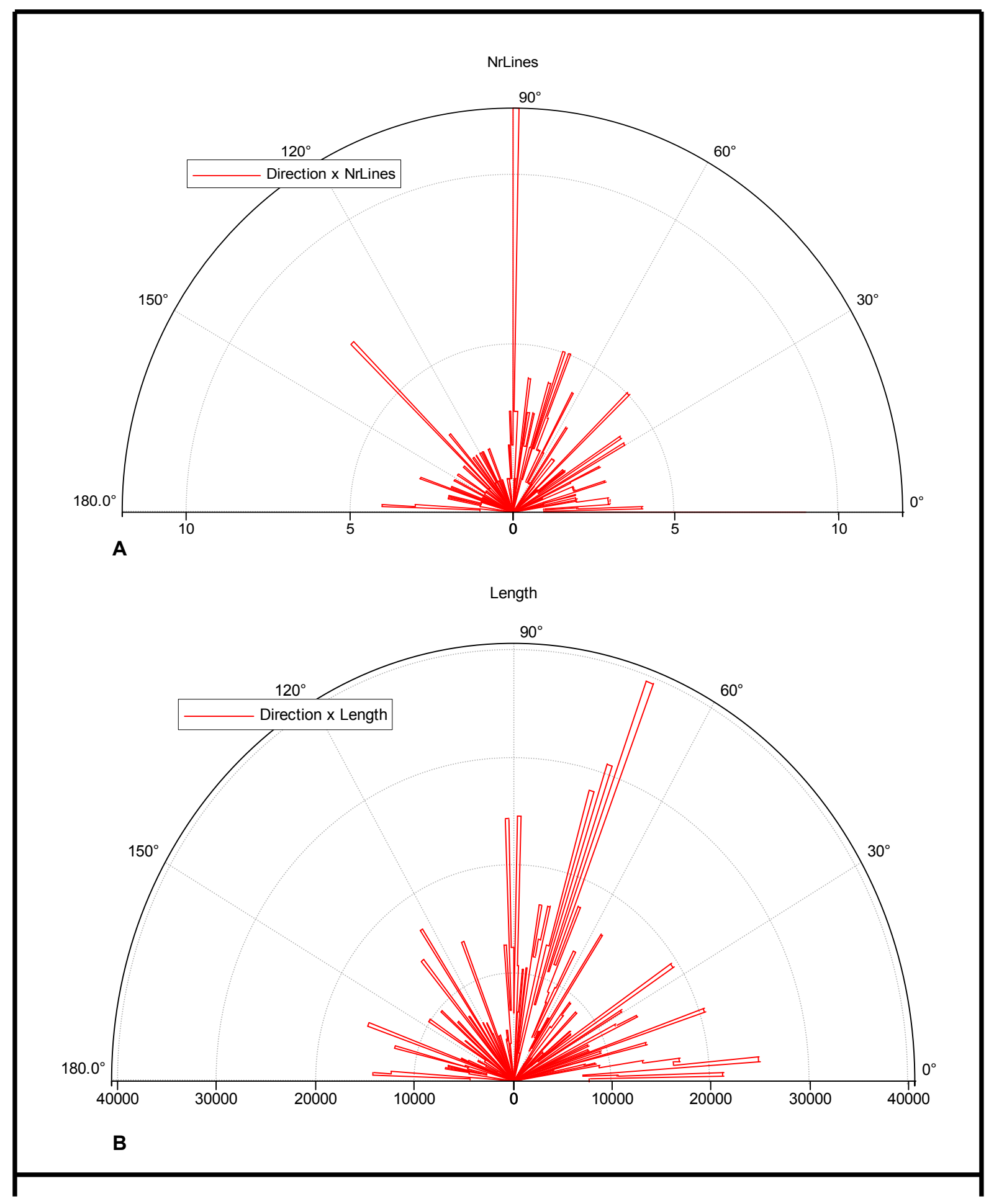

Fig. 3: Azimuth frequency/length curves for the lineament of the study area 


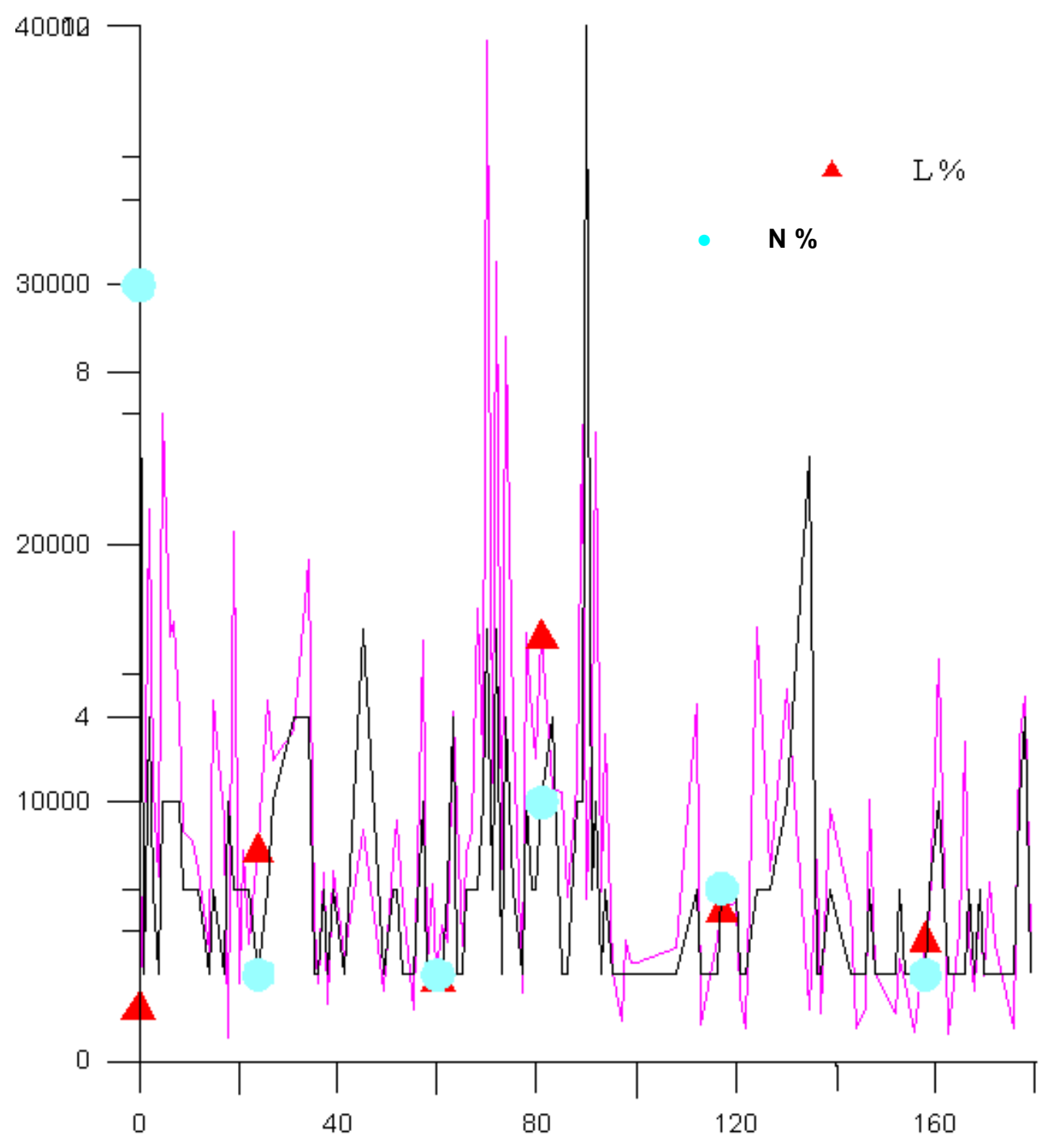

Fig. 4: Frequency / length curve of the lineaments of the study area

Thin sections of sampled rocks were studied with the transmitting polarizing microscope. The Migmatite-gneisses have very prominent foliations marked by more or less continuous alternating bands of light and dark colored minerals (Fig. 5). This foliation is approximately $\mathrm{N}-\mathrm{S}$ with variations between NE and NW. This parallel alignment is equally recognized in the schistose quartzite under the microscope. The foliation direction corresponds to the quartzite ridge and the general strike of most rocks in the study area, with an average strike direction of $029^{\circ}$. Mineral lineation is concordant with the main fault zone which strike is about $020^{\circ}$.

Mineralogically, migmatite-gneiss is rich in quartz, biotite, chlorite, plagioclase, microcline and quartz. The microfabrics are apparently consistent with major lineaments on the geological map. The nearly E-
W lineament which Oluyide (1988) described as the oldest is represented by $S_{1}$ direction. This is well represented in the lineament map (Figure 2). The structure probably resulted from directed pressure which could be described as the first episode of deformation $\left(D_{1}\right)$. This $D_{1}$ structure is affected by both ductile and brittle deformations $\left(D_{2}\right)$ which invariably created fold closures at all scales with axes which are almost N-S (Figure 5). Similar fold is shown in Figure 6. Apart from this, dominant transpose foliation on the gneisses and quartz, dextral sense of shear and some of the ductile $\mathrm{N}-\mathrm{S}$ shear zones were equally formed during this deformation episode. This almost obliterated $S_{1}$ surface which is preserved in porphyroclasts (Figure 7). Oluyide (1988) noted that the oldest E-W lineaments in Nigeria's basement have been largely obliterated but preserved in few places. 


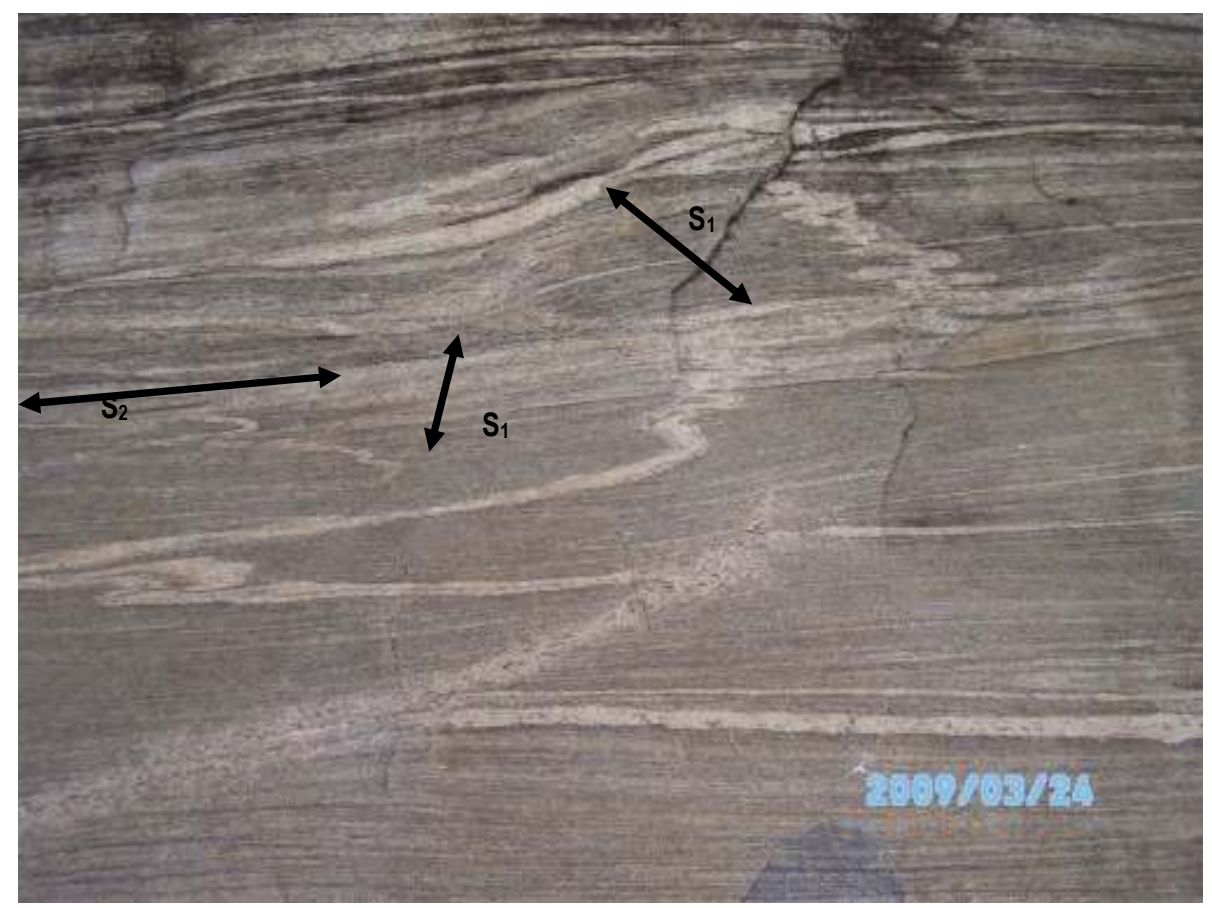

Fig. 5: Strongly foliated migmatite-gneiss in the study area. Note the microfolds in $S_{1}$ surface.

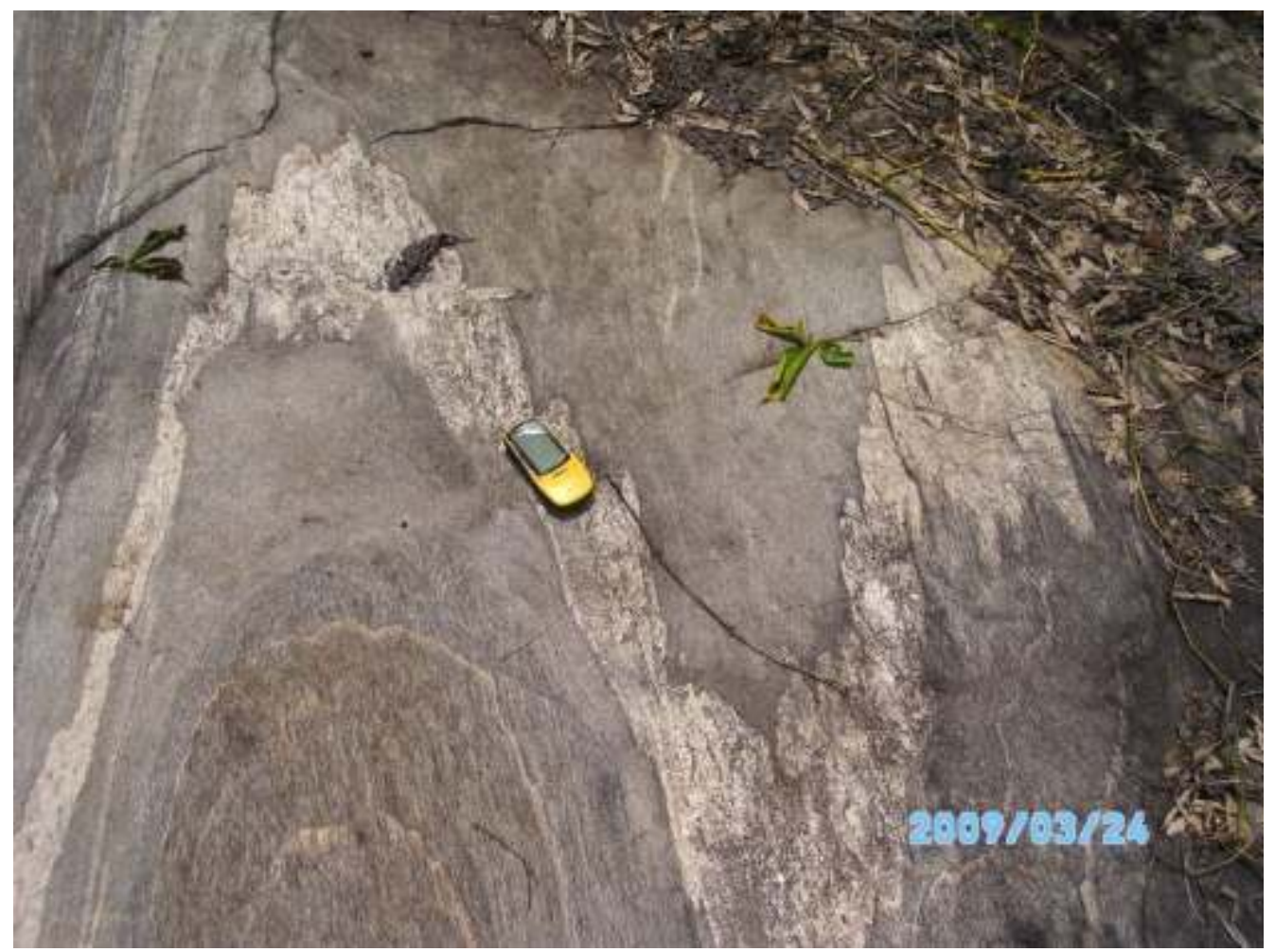

Fig. 6: Photograph showing folded pegmatite vein (this symmetrical fold is associated with $D_{2}$ ). 


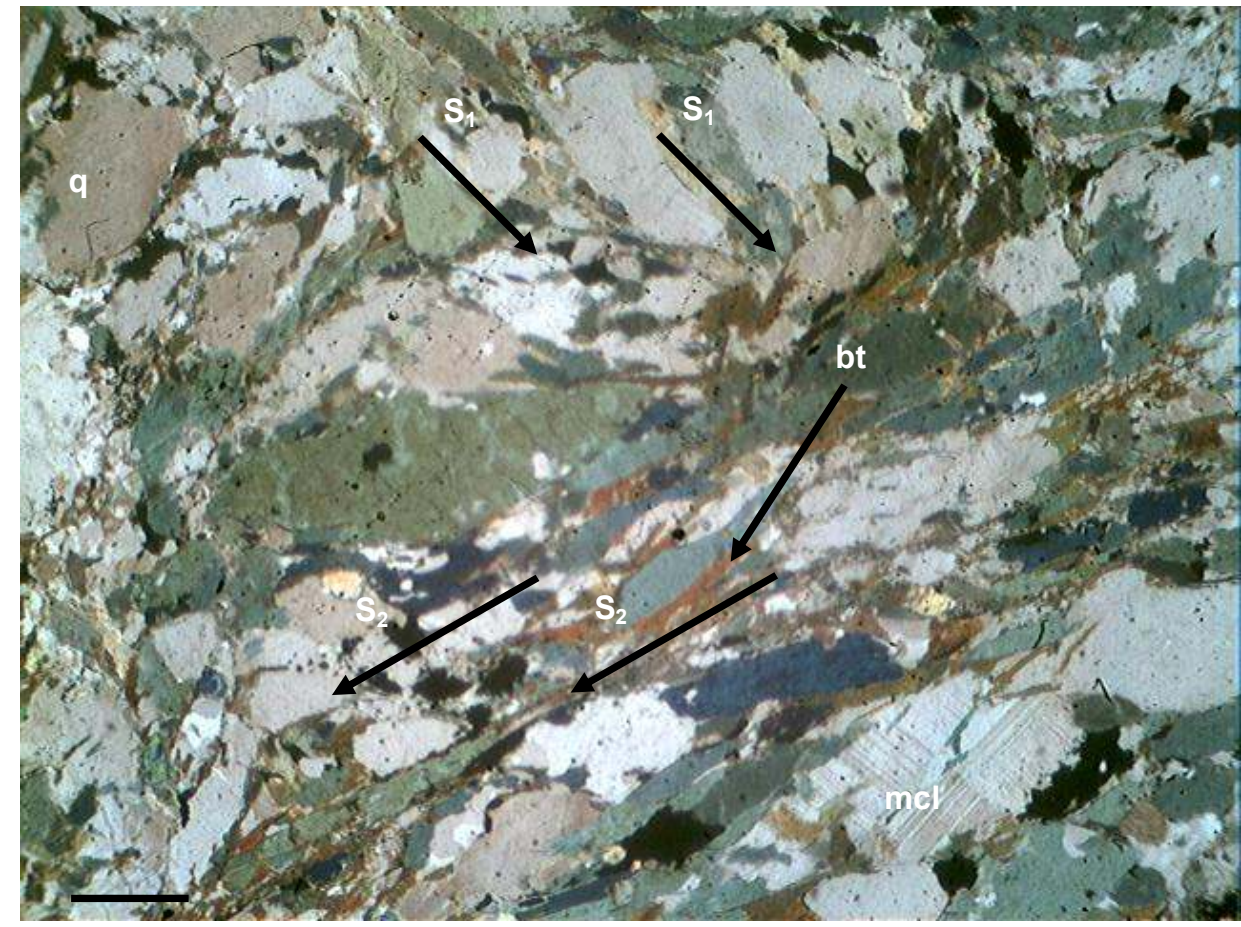

Fig. 7: Photomicrograph of migmatite gneiss showing microcline $(\mathrm{mcl})$, quartz (q), biotite (bt), and different foliation directions (Cross polars, Bar Scale: $2 \mu \mathrm{m}$ ).

\section{CONCLUSIONS}

Omifunfun area is characterized by low density lineaments. These lineaments have three prominent directions at $000^{\circ}-035^{\circ}$ and $060^{\circ}-090^{\circ}$, with minor one in NW-SE direction. These directions correspond to two major planar surfaces $S_{1}$ and $S_{2}$. The most prominent, Ifewara mylonitic foliation $\left(S_{2}\right)$ corresponds to the most prominent lineament directions. The two sets of structures are products of both brittle and plastic deformations. This further corroborates earlier works [Caby and Boesse, 2002; Odeyemi, 1993) that the linear structures $\left(S_{1}\right.$ and $\left.S_{2}\right)$ in the study area resulted from two deformation episodes $\left(D_{1}\right.$ and $\left.D_{2}\right)$.

\section{REFERENCES}

Ajibade, A. C and Wright, J. B., 1989. The Togo Benin Nigeria Shield: evidence of crustal aggregation in the Pan African Belt. Tectonophysics; (165): 125-129.

Black, R., Latouche, L., Liegeois, J. P., Caby, R and Bertrand, J. M., 1994. Pan African displaced terrains in the Tuareg shield (central Sahara). Geological Magazine; (22): 641-644.

Caby, R and Boesse, J. M., 2002. Pan-African nappe system in southwest Nigeria: the Ife-llesha Schist Belt. Journal of African Earth Sciences; 33, (2): 211-215.

Hubbard, F. H., 1975. Precambrian crustal development in Western Nigeria: indications from the Iwo region. Geological Survey of America Bulletin, (86): 548-564.

Odeyemi, I. B., 1993. A comparative study of remote sensing images of the structure of Okemesi fold belt, Nigeria. ITC Journal, (1): 77-81.

Odeyemi, I. B., 1998. The fracture zones and seismicity along Nigeria coast. The Nigerian Journal of Science; (28): 9-21.

Oluyide, P. O., 1988. Structural trends in the Nigeria basement complex. In: Oluyide PO (Coordinator), Precambrian Geology of Nigeria, Geological Survey of Nigeria, Kaduna: 93-98.

Rahaman, M. A., 1988. Recent advances in the study of the basement complex of Nigeria. In: Oluyide PO (Coordinator), Precambrian Geology of Nigeria, Geological Survey of Nigeria, Kaduna: $11-43$.

Udoh, A. N., 1988. An interpretation of satellite imageries of Nigeria $7^{\circ} 40^{\prime} \mathrm{N}$. In: Oluyide PO (Coordinator), Precambrian Geology of Nigeria, Geological Survey of Nigeria, Kaduna: 99-102. 
